\title{
A Mixed-Method Analysis of Fatal Attacks on Police by Far-Right Extremists
}

\author{
Jeff Gruenewald \\ Kiefer Michael G. Dooley \\ Michael J. Suttmoeller \\ Steven M. Chermak \\ Joshua D. Freilich
}

\begin{abstract}
Several recent high-profile homicides of police officers have brought increased attention to issues of far-right extremist violence in the United States. We still, however, know very little about why (and how) certain encounters between far-right extremists and police result in violence. To fill this research gap, we conduct a mixed-method analysis of far-right police homicides based on quantitative and qualitative data from the United States Extremist Crime Database (ECDB). We begin by categorizing cases based on key aspects of homicide storylines. We then comparatively analyze attributes of event precursor, transaction, and aftermath stages across four storyline categories. Finally, a case study is purposively selected to follow-up on each storyline category to better capture the nuances of fluid homicide processes. Our findings have important implications for identifying triggering events, escalation factors, and other situated sets of conditions and circumstances that contribute to deadly outcomes for police officers.
\end{abstract}

This is the author's manuscript of the article published in final edited form as:

Gruenewald, J., Dooley, K. M. G., Suttmoeller, M. J., Chermak, S. M., \& Freilich, J. D. (2016). A Mixed-Method Analysis of Fatal Attacks on Police by Far-Right Extremists. Police Quarterly, 19(2), 216-245. 


\section{A Mixed-Method Analysis of Fatal Attacks on Police by Far-Right Extremists}

Several recent high-profile homicides of police officers have brought increased attention to issues of far-right extremist violence in the United States. ${ }^{1}$ While deadly attacks on police by domestic extremists represent only a small portion of all police homicides, research suggests that violent far-rightists pose a threat that is more concerning to police than other types of terrorists, including radical Islamist terrorists (Carter, Chermak, Carter, \& Drew, 2014). This threat is made even more tenable when considering the beliefs held by those in the extremist movement. Many far-rightists, for instance, demonize police by characterizing them as governmental foot soldiers enforcing policies that threaten American's rights and liberties. Pervasive far-right conspiracy theories suggest that the government is intent on systematically disarming its citizens, amplifying their distrust of police and, for some, neutralizing moral barriers to violence. Symbolic of a despised government and exposed to the public, police officers serve as practical targets of extreme far-right violence (Gibbs, 2013).

In this study, however, we suggest that it is also necessary to move beyond offenders' ideology to understand the circumstances in which deadly acts of violence against police materialize. Anecdotally, it is possible to surmise that some extremist attacks against police are planned, while other attacks emerge more organically during seemingly routine exchanges with police. Reports by extremist watch-groups have taken note of violence against police, warning them to be wary of far-right extremists during traffic stops (ADL, 2001). Still, there has been

\footnotetext{
${ }^{1}$ Harris, D. (2010, July 1). Deadly Arkansas shootings by 'Sovereigns' Jerry and Joe Kane who shun U.S. law. ABCNews. Available from http://abcnews.go.com/WN/deadly-arkansas-shooting-sovereign-citizens-jerry-kanejoseph/story? id=11065285\&singlePage=true; Levit, I. (2014, June 9). Antigovernment obsession preceded Las Vegas shootings. New York Times. Available from http://www.nytimes.com/2014/06/10/us/couple-in-las-vegaskillings-embraced-anti-government-ideology.html? $\mathrm{r}=0$
} 
little research on the situated dangers of police encounters with far-rightist extremists.

Importantly, we suggest that a more nuanced understanding of these violent crimes is needed to illuminate opportunities for early prevention and the de-escalation of extremist violence.

Therefore, the purpose of the current study is to further our understanding of these dynamic homicides by uncovering the situated circumstances in which far-right homicide events emerge and escalate into deadly outcomes for police.

In this study, we examine homicides targeting police using data from the United States Extremist Crime Database (ECDB), an open-source database and archive of publicly available materials related to domestic extremists' crimes. $^{2}$ While there is still no consensus definition of a far-right extremist (see Michael, 2003), this term has been used to describe a variety of individuals and groups who adhere to White supremacist and anti-government belief systems (Barkun, 1997; Berlet \& Vysotsky, 2006; Hewitt, 2003; Hoffman, 1987; Neiwert, 1999; Perliger, 2012; Smith, 1994). ${ }^{3}$ We will rely on the ECDB's definition of a far-right extremist, which was

\footnotetext{
${ }^{2}$ Data from ECDB has also been used in previous research to successfully examine issues, such as extremist group dynamics (Freilich, Chermak, \& Caspi, 2009), differences between violent and non-violent extremist groups (Chermak, Freilich, \& Suttmoeller, 2013), differences between far-right homicides and "regular" non-extremist homicides (Gruenewald \& Pridemore, 2012), lone wolf extremist violence (Gruenewald, Chermak, \& Freilich, 2013a; 2013b), ideologically motivated victimization (Parkin, Freilich \& Chermak, 2015; Parkin \& Freilich, 2015), and county-level variations in extremist attacks (Chermak \& Gruenewald, 2015; Freilich, Adamczyk, Chermak, Boyd, \& Parkin, 2014).

${ }^{3}$ While racial purity and anti-government sentiment are two fundamental tenets of far-right extremism, the movement encompasses an assortment of individuals and groups that vary in regards to their particular ideological beliefs and grievances. More specifically, the extreme far-right movement includes members of the Ku Klux Klan (KKK) and other White supremacist groups (Arena \& Arrigo, 2000; Bushart, Craig, \& Barnes, 1998; Flint, 2001; Hewitt, 2000; Sprinzak, 1995), as well as prison-based, criminal organizations like the Aryan Brotherhood (Fleisher \& Decker, 2001; Irwin, 1980; Orlando-Morningstar, 1997; Pelz, Marquart, \& Pelz, 1991). Other far-rightists affiliate more with the racist, religious belief system of Christian Identity (Aho, 1990; Arena \& Arrigo, 2000; Barkun, 1997; Hoffman, 1987, 1995; Kaplan, 1993; Sharpe, 2000; Smith, 1994), the neo-Nazism and the skinhead subculture (Ezekiel, 2002; Hamm, 1993; Whitsel, 2001), or anti-government militia and Christian patriot groups (Barkun, 1996; Durham, 1996; Levitas, 2002; Neiwert, 1999). Still other far-rightists are driven by more narrow ideological concerns, including the provision of abortions (Blanchard, 1996; Carlson, 1995; Grimes, Forest, Kirkman, \& Radford 1991; Kaplan, 1996; Wilson \& Lynxwiler, 1988). Currently, a leading concern to police are antigovernment protestors who refer to themselves as sovereign citizens, or far-rightists that reject U.S. citizenship and associated responsibilities, including paying taxes and registering personal identification papers with the government (Anti-Defamation League, 2012; Federal Bureau of Investigation, 2011).
} 
derived from a systematic review of the extant literature (Gruenewald, Freilich, \& Chermak,

2009). Specifically, we maintain that extreme far-rightists,

“... are fiercely nationalistic, anti-global, suspicious of federal authority and reverent of individual liberties, especially their right to own guns and be free of taxes. They believe in conspiracy theories involving imminent threats to national sovereignty or personal liberty and beliefs that their personal or national 'way of life' is under attack. Sometimes such beliefs are vague, but for some the threat originates from specific racial or religious groups. They believe that they must be prepared to defend against this attack by participating in paramilitary training or survivalism (Freilich, Chermak, Belli, Gruenewald, \& Parkin (2014, p. 380). ${ }^{4}$

The following questions will guide the remainder of our exploratory study. First, how do deadly extreme far-right attacks against police develop, transpire, and end? Second, how do event-level processes compare across homicides that are committed under different sets of conditions and circumstances?

\section{Prior Literature}

Though several important criminological studies have examined police homicides in the past,${ }^{5}$ the prior literature reveals little about those that have specifically been perpetrated by farright extremists. Others have also studied trends in far-right violence (Hewitt, 2003; Kaplan, 1995; Perliger, 2012), and more specifically, far-right homicides (Gruenewald, 2011;

Gruenewald \& Pridemore, 2012; Parkin, Freilich, \& Chermak, 2014). This research, however, has yet to examine anti-police attacks by domestic extremists as a distinct category of lethal violence.

\footnotetext{
${ }^{4}$ Members of mainstream conservative political movements (e.g., Tea Party) and the mainstream Christian right are not included in this definition of the extreme far-right. Importantly, for a homicide offender to be considered a farright extremist and included in our study (see footnote 10 for list of extremist indicators), the offender must also be charged in relation to an anti-police killing or killed following a fatal attack against police.

${ }^{5}$ Some studies have sought to explain macro-level trends in of homicides targeting law enforcement (Batton \& Wilson, 2006; Chamlin, 1989; Jacobs \& Carmichael, 2002; Kaminski, 2004, 2008; Kaminski \& Marvel, 2002;

Kaminski \& Stucky, 2009; Lester 1978a, 1978b, 1984; Peterson \& Bailey, 1988), while other studies have provided descriptions of incident-, offender-, and victim-level characteristics of law enforcement officer homicides (Brown \& Langan, 2001; Carderelli, 1968; Chapman, 1986; Edwards, 1995; Konstantin, 1984; Little, 1984; Pinizzotto \& Davis, 1992; Wilbanks, 1994).
} 
Currently, we are aware of only two exceptions. In the first study, Suttmoeller, et al. (2013) compared various background and situational characteristics of deadly far-right attacks against police in comparison to "routine" police killings. Several interesting findings from this study emerged, including that far-right offenders were on average several years older than most homicide offenders who target police. A second study by Freilich and Chermak (2009) analyzed situational factors observed in two far-right extremist attacks on police officers using a "script analysis" approach. In their study, they explored how "hard" and "soft" situational crime prevention techniques could be adopted to de-escalate volatile encounters with far-right extremists.

While this pair of studies has advanced our understanding of extremist violence against police, neither is without limitation. Thus far, research has conceptualized attacks on police as static offender attributes and one-dimensional acts of violence. Consequently, previous studies have painted an incomplete portrait of how homicide processes are structured and evolve from when violence is initially triggered until the violent event has been completed. We suggest that this is due in part because of the limited methodological approaches that have been used in prior research on extremist violence. Rather than analyzing homicides either quantitatively or qualitatively, we suggest that a mixed-method approach combining illustrative case studies to explicate quantitative results is a more useful approach for producing rich, nuanced descriptions of fluid homicide processes (Thaler, 2015; see also Cresswell \& Plano Clark, 2007; Tashakkori $\&$ Teddlie, 1998).

We also contend that prior studies have yet to consider the heterogeneity in underlying motives of far-right extremists who target police officers. It is unlikely that far-rightists who attack police are purely ideologically motivated. Instead, we expect that a mix of idiosyncratic, 
instrumental, and expressive motives fuel many extremist attacks on police officers. Therefore, to develop more informed policies and police practices for preventing and de-escalating violent situations, we examine how offender ideology and motives structure the various ways that farright ant-police homicide situations are triggered, escalate, and culminate into deadly outcomes for police.

\section{Approach to Current Study}

The initial step in our analysis is the construction of "storylines" for each homicide. Agnew (2006) has conceptualized a criminal storyline as, "a temporally limited, interrelated set of events and conditions that increases the likelihood that individuals will engage in a crime or a series of related crimes" (p.121). These conditions extend beyond common background and situational variables that are most commonly studied in criminological research. While criminal storylines may be virtually limitless, Agnew (2006) suggested that some storylines, such as those involving a desperate need for money or an unresolved dispute, are commonly occurring narratives found in many crimes. In our study, we use open-source materials to recreate homicide narratives and categorize storylines based on why extreme far-right offenders targeted police officers for victims of deadly violence. A narrative, or storyline, of each homicide is created based on a complete review of all available open-source materials. ${ }^{6}$ Storylines consist of information about the immediate circumstances shaping offenders' decisions to engage in acts of violence against police. By relying on offenders' own words and witness testimonies available in open-source materials, we include information about offenders' interpretations of unfolding

\footnotetext{
${ }^{6}$ The second author originally constructed storylines for each of the homicides included in our study. The primary author then filled in any missing details about the immediate homicide circumstances based on the same opensource materials. In the instance of conflicting open-source accounts, traditionally trusted sources of information (e.g., court documents and police reports) were assumed to be the most accurate and credible. Ultimately, having multiple accounts of each case helped to ensure the authentic recreation of homicide storylines (see Freilich et al., 2014).
} 
situations and their decisions to kill police officers. The purpose of our storyline analysis is to identify the primary reason why extreme far-rightists attacked police by reconstructing the specific conditions and circumstances making deadly violence seem justifiable or necessary. While there are many shared circumstances across homicide events, we found that each case best aligns with one of four mutually exclusive storyline categories.

We next quantitatively examine aggregated attributes of homicides across the four storylines to better understand differences in the ways that police homicides occur. Adopting Meier, Kennedy, and Sacco's (2001) criminal event perspective, we conceptualize homicides as multi-dimensional events that are situated within particular environmental and behavioral contexts. The criminal event perspective maintains that criminal events unfold over the course of three successive junctures, including precursor, transaction, and aftermath stages. The precursor stage encompasses specific circumstances leading victims into contact with offenders. It is during this precursor stage that key triggering events spark processes that spiral into criminal outcomes. The transaction stage is comprised of dynamic exchanges between offenders and victims occurring within specific situational (geospatial and temporal) contexts. This stage encompasses the initiation and escalation of violence, and often the introduction of weapons and bystanders to already volatile situations. Finally, the aftermath stage includes offender behaviors and interactions with others following the completion of violent transactions. Examples of aftermath behaviors include continued criminal activity, offender escape, the staging of a standoff, or offender suicide.

This approach draws heavily upon symbolic interactionism, or the study of how social behavior is shaped by how actors' define their roles and the cues or "scripts" of situated social exchanges (Blumer, 1969; Goffman, 1959). In the past, some studies have relied on an 
interactionist approach to examine the drama of violence (Collins, 2008), and more specifically, situated homicide transactions (Athens, 1980; Luckenbill, 1977). In this same vein, our interest in this study is not simply in the homicide "act" but the dynamic circumstances leading to the interaction, the social context, and activities occurring following the criminal behavior (Meier et al., 2001; see also Sacco \& Kennedy, 1996). In short, we rely on criminal event analysis to examine "...those conditions - immediate and relatively close to the act - as well as other, more removed but still relevant factors, that are implicated in the occurrence of the crime" (Meier et al., 2001, p. 3).

The last step of our study is the comparative case study analysis of four homicides, purposively selected to represent each of the storyline categories. Because the quantitative results capture only static attributes associated with each of the storyline categories, we supplemented them with case studies to more aptly exemplify the fluid nature of each homicide processes as they unfold over time and in space. While homicide storylines capture the immediate circumstances suggesting why offenders' decided to kill police, case studies encompass a more holistic description of how homicide events occurred. Of particular interest is in how combinations of situational attributes, offender backgrounds, and victim provocations interact within dynamic social settings to result in fatal outcomes for police officers.

\section{Data and Method}

This study utilizes data from the United States Extremist Crime Database (ECDB), ${ }^{7}$ an open-source, event-level database that tracks violent and financial criminal activities of domestic

\footnotetext{
${ }^{7}$ The ECDB project is co-led by Drs. Steven of Michigan State University and Joshua D. Freilich of City University of New York, John Jay College of Criminal Justice. Since 2006, the project has received funding from the Department of Homeland security through the National Consortium for the Study of Terrorism and Responses to Terrorism (START), and the National Institute of Justice (NIJ). In the past, the ECDB has been shown to be a valid source of data on extremist crime (Chermak, Freilich, Parkin, \& Lynch, 2012; Freilich, Chermak, Belli, Gruenewald, \& Parkin, 2014).
} 
extremists. Our analysis includes 30 cases of extremist far-right anti-police ${ }^{8}$ homicide that occurred between January 1, 1990 and June 30, 2014. ${ }^{9}$ Official crime data sources currently lack identifying information on police killings perpetrated by extreme far-rightists, therefore the ECDB identifies homicide cases from various open-sources, such as advocacy group reports, journalist accounts, and scholarly publications. From the ECDB, we extract existing quantitative data on a series of variables, as described in more detail below, as well as qualitative data consisting of open-source materials that amount to hundreds of pages of electronically stored documents. The open-source information is used to open-code for several additional variables not previously included in the ECDB, create homicide narratives or "storylines," and conduct indepth case studies.

For a homicide to be included in the current study, it must be perpetrated by one or more far-right extremist ${ }^{10}$ who intentionally targeted police officers acting in the line of duty. The ECDB includes 30 such homicides that meet these criteria. Though a relatively small set of

\footnotetext{
${ }^{8}$ While the ECDB also collects data on extremist homicides targeting correctional officers, judges, other government officials, and private security officers, these cases were not included in the current study. In addition, while the ECDB collects data on extremist homicides against police officers who were not on duty at the time of their death, these cases were not included in the current study. Data collection was restricted from 1990 to 2014 because these were the years that anti-police homicide data were available from the ECDB. Collecting open-source data on extremist crimes prior to 1990 becomes increasingly challenging due to the lack of information from publicly-available sources, such as digitalized news media.

${ }^{9}$ The ECDB's incident identification and coding is a multi-stage process (Freilich et al., 2014). To begin, opensource publications (e.g., the FBI's Terrorism in the United States annual reports, the Global Terrorism Database, and Southern Poverty Law Center's Intelligence Report) and online newspaper articles are used to identify extremist crimes. Key indicators of far-right extremism were applied systematically to all 30 anti-police homicide cases (see footnote 10). Information is then gathered from more than 30 open-source search engines and databases to collect all publically available information on each crime. Coders then scour all related materials to verify that the incident met the inclusion criteria, conduct additional, targeted open-source searches, and code a series of established incident-, offender-, and victim-level variables, as well as variables capturing the reliability of the open-source documentation. For a more in-depth discussion of the methodology, please see Freilich et al., (2014) and Parkin and Freilich (2015). ${ }^{10}$ The most common ways that association with the far-right movement is identified is through evidence of selfadmission to White supremacy or anti-government sentiment, patriot, militia, or other hate group membership, possession of far-right literature, bodily markings (e.g., tattoos), previous involvement in specific criminal and noncriminal far-right activities, and other verbal or written documentation of ideological beliefs. Again, for an offender to be included in our study, he or she must also be charged in relation to an anti-police killing or killed following a fatal attack against police.
} 
homicide cases, we believe that our study captures all far-right anti-police homicides occurring in the last 25 years for which information about offenders' extremist affiliations is publicly available. The majority of the homicides included involved perpetrators who adhered most strongly with anti-government belief systems $(n=19,63 \%)$, as opposed to racial purity or White supremacy $(n=11,37 \%) .{ }^{11}$ Most incidents were perpetrated by either anti-government offenders unaffiliated with extremist organizations or those who identified as sovereign citizens (40\%), while other incidents involved Aryan prison gang members (16.7\%), militia members (13.3\%), unaffiliated White supremacists $(10 \%)$, adherents of the Christian Identity movement ${ }^{12}(6.7 \%)$, neo-Nazi skinheads (6.7\%), and apocalyptic survivalists $(6.7 \%)$. The majority of far-right homicides targeting police involved offenders who were previously known to law enforcement. In fact, over 60 percent of homicides were perpetrated by offenders with known prior arrests for violent crimes. In addition, nearly 40 percent of the homicides were committed by extreme farrightists who had made previous threats of violence against government agents, including judges, police officers, and other public officials. ${ }^{13}$

Forty-three far-rightists, all White and 90 percent male, were directly involved in the homicides. ${ }^{14}$ In this way, far-right police homicide offenders differ from other offenders who kill police officers, as they tend to be somewhere between 40 and 46 percent non-White (Brown \&

\footnotetext{
${ }^{11}$ When offenders with a central ideological concern of maintaining racial purity killed government agents, they were largely members of White supremacist prison gangs (e.g., Aryan Brotherhood).

${ }^{12}$ Many Christian Identity adherents believe that Whites are the true chosen people and consider Jews and racial minorities to be "subhuman" (see Barkun, 1997; Baysinger, 2006; Brannan, 1999).

${ }^{13}$ For approximately 20 percent of cases in which threats were made, evidence of mental illness for one or more offenders was evident in open-source materials.

${ }^{14}$ The ECDB includes data on 43 offenders whose affiliations with the extreme far-right movement could be established. Only four of the offenders were female, and all female offenders played a more supportive rather than leading role in the homicide. For instance, in one case, a female lured two officers into her hotel room under the guise of cooperating with an investigation. As she closed the door behind them, her boyfriend opened fire, killing two officers.
} 
Langan, 2001; Konstantin, 1984; Little, 1984; Pinizzotto \& Davis, 1992). Only one far-right offender was under the age of 18 (2.3\%), while eight offenders were young adults (18 to 24 years of age). The majority of offenders were between 24 and 39 (44.2\%), and approximately a quarter of far-rightists were between 40 and 59. As the average age of most police homicide offenders is approximately 26 (Pinizzotto \& Davis, 1992), or slightly older (Chapman, 1986; 1998), farrightists who kill police compare similarly in age to non-extremist offenders (see also Suttmoeller et al., 2013).

\section{Description of Variables}

We also include several variables designed to capture key elements of homicide event stages to include in our descriptive analysis. We begin by including two open-coded measures thought to potentially influence the escalation of violence and deadly outcomes. The first precursor variable is the triggering event, or the specific act that initiated contact between offenders and police officers, setting the homicide in motion. The second precursor variable captures the immediate warning signs, ${ }^{15}$ or readily apparent cues that could lead officers to believe that the offender will possibly become violent.

Next, several variables aiming to capture elements of the homicide transaction stage are included. The first is the initiation of violence, another open-coded variable pertaining to acts performed by either offenders or police officer victims that operate to transform initial interactions into violent encounters. Initiators of violence happening during the transaction stage are unique from precursor triggering events as they occur after homicide participants are already engaged in a social exchange. Second, we capture escalation factors, or acts engaged in by involved parties at the homicide scene that serve to intensify situated transactions following the

\footnotetext{
${ }^{15}$ We refer to this variable as "immediate warning signs" to distinguish them from more advanced warning signs that may emerge days, weeks, or even years prior to the homicide.
} 
initiation of violence. Third, we code for the presence of bystanders (yes or no), or third parties, who contribute in some way to the deadly outcomes of the homicide event. The remaining transaction stage variables are discrete measures that have previously been systematically coded for by the ECDB. Fourth, we code for the weapon type used in the homicide (single handgun, single assault rifle, other long gun, multiple weapons, or bomb). Fifth and sixth, we include variables measuring the number of far-right offenders (1, 2, 3 or more) involved in the homicide, and the number of officers killed (1, 2, 3 or more) in the homicide, respectively. The seventh transaction stage variable is offender intoxication (yes or no), which assesses whether or not offenders were under the influence of drugs or alcohol, and thus acted with lowered inhibitions during the transaction stage of the homicide event.

We also include several variables capturing specific circumstances that might occur in the aftermath of violent transactions, or the last stage of homicide events. First, we measure whether or not there was an arrest of one or more offenders (yes or no), and second, whether or not a death of one or more offenders (yes or no) occurred. Third, we include a variable capturing whether or not one or more offenders committed a subsequent crime following the initial homicide (yes or no). Fourth, we measure whether or not one or more offender fled (yes or no) the scene of the crime after a police officer was mortally wounded. Fifth, for those cases involving offenders who fled the crime scene, we also open-code the flight path or destination of the offender. The last two variables are designed to elicit information about offender standoffs with police officers. Sixth, we include the transaction stage variable standoff with police (yes or no) following the initial homicide, and finally, for those homicides ending with a standoff with police, we open-code open-source information about the conclusion of the standoff. 


\section{Results}

Based on our review of each storyline, four categories that are distinguishable by the ultimate purpose for killing police officers emerged. The first category captures the avoiding arrest storyline $(\mathrm{n}=14)$, which includes homicides perpetrated by extreme far-rightists who had recently committed prior crimes and were running from the law. Far-right fugitives believed that violence was necessary to escape capture by police. The second homicide storyline category involves mission offenses $(\mathrm{n}=8)$, which are committed by offenders who are intent on making an ideological statement by murdering police officers. This type of offender was unique from all others in that their violence was planned rather than in reaction to the presence or actions of police officers. Mission offenders engaged in violence to prove a point, rectify perceived wrongs, or incite a revolution against the government. The third category of homicide is defending property $(\mathrm{n}=6)$, which are committed by far-rightists who viewed the presence of police on their property as a threat to their civil liberties, way of life, and freedom. The fourth and final storyline category is defending family $(\mathrm{n}=2)$. This storyline occurs when far-rightists perceive police officers to be an imminent threat to their family. In these cases, the threat posed by police is neutralized to allow for a possible escape.

In Table 1 below, we display our results for the precursor variables of interest, and then separately by homicide storyline category.

$<<<<<<<<<<<<<$ INSERT TABLE 1 ABOUT HERE $>>>>>>>>>>>>>>$

The precursor stage of criminal events, typically an overlooked dimension of crime (Meier et al., 2001), entails the initial contact between homicide participants and the immediate warning signs that manifest just prior to violent transactions. Precursor activities are critical for setting criminal event processes in motion. Based on our analysis, it is clear that the majority of attacks against 
police officers occurred during traffic stops. While every homicide storyline category involved at least one case triggered by a traffic stop, we also see that each of the defending family homicides also emerged from traffic-related circumstances. In both instances, evidence suggests that farrightists targeted police in defense of a family member who was arguing or engaged in a physical altercation with police. Response to calls and routine police activity are the next modal triggering events. Responses to 911 calls are common triggers for defending property homicides, often stemming from calls regarding the brandishing of weapons or other threatening behaviors. Routine police activity triggers are operationalized as duties other than responding to calls for service and assorted police duties. For example, officers were killed by far-rightists as they rested in their cruisers and ate lunch. For mission offense homicides, triggers were usually routine police activities (62.5\%), and committed when officers had let down their guard. Finally, in 30 percent of cases, the initiation of arrests and police responses to crimes being committed were triggers for violence that manifested during the precursor stage.

In over half of our cases, far-right offenders failed to display warning signs immediately preceding their attacks, and no immediate warning signs were displayed consistently across all storyline categories. Not surprisingly, the mission offense storyline has the largest percentage of cases $(75 \%)$ where no immediate warning signs were displayed. When warning signs were present in the precursor stage of the homicide, the most common was police knowledge that farright offender possessed weapons (20\%). For example, in half of defending property homicide cases, police officers approached the scene with knowledge that offenders were armed. In relatively fewer cases, police officers had knowledge of offenders' extremist ideologies (10\%), direct warnings by offenders of their intent to use violence $(6.7 \%)$, or belligerence indicative of adherence to an extreme far-right ideology (6.7\%). 
As previously mentioned, the transaction stage encompasses the initiation of violence, escalating factors, and ultimately, the deadly act of violence that results in the death of police officers. As shown in Table 2, nearly half of all violent transactions were initiated by surprise attacks on police officers, also constituting the majority of violent initiators for both the avoiding arrest and mission offense storyline categories. These attacks generally occurred during traffic stops or as police officers investigated suspicious activities. Surprised officers rarely had time to respond in a defensive manner, as offenders were able to "get the drop" on them. Ambush attacks constituted the next most common majority of all attacks (20\%), occurring when officers were gunned down by an offender who was lying in wait. This was frequently the case for defending property offenders who believed that officers entering their properties were in violation of their rights.

$<<<<<<<<<<<<<$ INSERT TABLE 2 ABOUT HERE $>>>>>>>>>>>>>$

Extreme far-right offenders initiated violence by firing shots at an officer in four different cases (13\%). Officers were able to respond to the situation by calling for backup, drawing their weapons, and returning fire at offenders. Only 10 percent of homicide events were initiated by officer actions, including the use of non-lethal and deadly force by police. In these cases, officers responded to the offender's belligerence with Taser strikes, physical restraint, and the use of their service weapons.

Also shown in Table 2, we found that observable escalation factors played no discernable role in over half of the homicides. In these cases, officers were quickly killed by a single act of deadly violence. These findings coincide with the proportionately large number of surprise attack and ambush cases included in our study. We also found that introductions of third party actions escalated violence in one fifth of the homicide cases. Third parties were often offenders' family 
members or significant others who appeared on the scene after the violence had been initiated. Third parties escalated violence in several ways, including supplying offenders with weapons, inciting primary offenders to continue violent acts, or in one instance, retrieving an incapacitated officer's weapon. In another one-fifth of cases, actions of police seemingly escalated violent interactions. One way that police escalated violence was through shows of authority and heavyhanded force. This was especially common for the defending property homicide storyline. By appearing on the crime scene in great numbers and with equipment symbolic of government and military force, police officers played into offenders' conspiracy theories and fears that government actors were specifically targeting them, so much that they needed to defend themselves at all costs. Another way that police escalated violence was by engaging in "hero" endeavors. That is, police officers escalated violence by either failing to wait on support or by placing themselves in significant danger to aid downed comrades, sometimes resulting in the death of one or more additional officers.

Overall, our findings revealed that the majority of fatal transactions involved a single farright offender armed with a firearm who targeted a single police officer. More than one offender was present in roughly 37 percent of our cases, while a bystander played a role in nearly half of the homicides. The death of more than one officer occurred in 30 percent of the cases, and cases in which three or more officers were killed were even rarer. One of the cases involving multiple police officer deaths was the 1995 mission offense bombing of the Alfred P. Murrah building in Oklahoma City. Cases with multiple offenders were represented across all homicide storylines, but almost 40 percent of all cases were perpetrated by lone actors. Multiple weapons and assault rifles were present most often in avoiding arrest and defending property cases where offenders were caught in the act of committing another serious crime or were at home with access to a 
cache of weapons. Only two of our cases involved bombings, both of which occurred as mission offenses. Finally, there was evidence of offender intoxication in only a few homicide cases, and there was only one homicide in which it appeared that lowered inhibitions due to alcohol shaped the deadly outcome.

Finally, we also examined the aftermath stage of homicides, which includes the behaviors of offenders immediately following the slaying of police officers, concluding the homicide event. As shown in Table 3, fleeing from the scene of the homicide occurred in the vast majority of cases $(70 \%)$. Far-right offenders chose to flee to various locations, including their own homes. Most often, offenders were able to effortlessly flee crime scenes because additional officers were not present on scene to prevent their escape.

$<<<<<<<<<<<<$ INSERT TABLE 3 ABOUT HERE $>>>>>>>>>>>>>$

The involvement of multiple police officers made fleeing more challenging for far-right offenders. Cases in which multiple officers were on scene involved car chases and escapes to wooded areas, retail stores, and random homes where offenders took hostages. The largest percentage of offender flights occurred in mission offenses $(88 \%)$, followed closely by avoiding arrest homicides (79\%). Mission offenders committed their attacks quickly and continued to commit further crimes as a violent way to bring additional awareness to their ideological cause. Avoiding arrest offenders, in contrast, fled in the hopes of escaping the law. In defending property cases, only 30 percent of offenders decided to flee. Instead, these offenders usually chose to make their ideological viewpoints clear before being killed by police or surrendering to authorities.

Nearly half of the offenders went on to commit further crimes after their initial homicide of police officers, usually as a means to further their escape efforts. This was especially true for 
avoiding arrest homicides in which offenders in over 57 percent of cases went on to commit additional crimes. These crimes included the slaying of another police officer in one avoiding arrest homicide, shooting at officers in four other homicides, and hostage taking and grand theft auto in two other cases. Some offenders committed crimes unrelated to police homicides, including theft, burglary, and assaults on unrelated individuals. Still, others went on to murder their partners, co-conspirators, or captives as responding police officers moved in and narrowed their chances for escape. These offenders also typically committed suicide to avoid arrest for their crimes.

A standoff occurred at some point during the homicide in 60 percent of the cases, ${ }^{16}$ though they were most common in avoiding arrest and defending property cases. Half of the standoffs concluded with an offender's surrender and arrest. In these cases, extreme far-rightists surrendered voluntarily or, in other instances, emergency response teams successfully apprehended and arrested them. Eight standoffs (44\%) concluded with the death of an offender, of which two were suicides. ${ }^{17}$ In these events, offenders chose death as a final means of escape. Three of the eight mission offense homicide events included a standoff. All three of these cases concluded with the offenders' death in a police shootout, reflecting their ideological inclination to ignite a revolution and take as many police officer lives as possible along the way.

Regardless of whether a standoff occurred, half of the homicides ended with at least one offender dying. On the whole, the majority of offender deaths occurred during shootouts with police, and all extreme far-right offenders engaged in shootouts with police in defending family cases. We also see in Table 3 that 53 percent of homicide events ended with the arrest of at least

\footnotetext{
${ }^{16}$ Fifty-seven percent of standoffs occurred in the aftermath stage, while three percent occurred in the transaction stage.

${ }^{17}$ As shown in Table 3, there were four total suicides in our study, all of which occurred during avoiding arrest cases, and two of which occurred during a standoff.
} 
one offender. Defending property cases saw the highest number of arrests with five of six cases concluding with the apprehension of the offender. Not a single offender escaped permanently, despite several temporary escapes from standoffs. The improbability of an offender's escape following the homicide of a police officer is likely due to widespread media coverage, national outrage, and a massive mobilization of government resources to aid in capturing far-right fugitives.

\section{Comparative Case Study Findings}

Comparing variable distributions across storyline categories reveals that not all far-right perpetrated anti-police homicides unfold in the same manner. Instead, each case involved extreme far-right actors who operated within unique sets of situated circumstances and environmental cues, which shaped their perceived roles and interpretations of fluid homicide events. Though useful for detecting broader patterns, our descriptive results fail to capture the mutability of homicide processes. Therefore, we expand on our findings by selecting representative cases from each homicide storyline category for purposes of comparative analysis. Previous research has found that case selection based on categorical schemes is a useful technique for the purposive identification of case studies (Bennett \& Elman, 2006). Utilizing an explanatory mixed-method design (Cresswell \& Plano Clark, 2007; Cresswell, Plano Clark et al., 2003), ${ }^{18}$ we identified cases exhibiting the largest number of modal homicide attributes for a particular storyline category, as indicated by our earlier quantitative analysis. ${ }^{19}$ The goal of our comparative analysis is to emphasize heterogeneity in dynamic criminal event processes across homicide storylines.

\footnotetext{
${ }^{18}$ The term "explanatory" is used here to indicate how qualitative analysis is used to "explain" or expound upon earlier quantitative findings.

${ }^{19}$ This mixed-method approach has been used by others in previous research on terrorism and extremist crimes (see Hamm, 2007; Kelley \& Gruenewald, 2015).
} 
Avoiding arrest. Our first homicide case was committed by a member of a racist skinhead group ${ }^{20}$ with a history of prior run-ins with the police and an extensive criminal record, including gun, drug, and other violent offenses. ${ }^{21}$ Though, like all racist skinheads, the offender harbored animosity toward racial and ethnic minorities, he had also clearly cultivated a disdain for the police. In this case, the avoiding arrest homicide began when the offender decided to burglarize the home inhabited by a former boyfriend of his female accomplice. ${ }^{22}$ Characteristic of avoiding arrest homicides, the initiating event in this case was the commission of a crime during the precursor stage of the homicide. Those living in the home called police to report the crime in progress, but the offenders were able to access their vehicles and flee the scene just as police arrived. A dangerous police chase ensued with the female accomplice at one point steering the car from the passenger's seat as the offender shot at pursuing officers. The chase ended at an apartment complex inhabited by a friend. Upon exiting their vehicles, the offender and his accomplice ran toward the apartments, firing several rounds in the direction of responding officers. His accomplice eventually surrendered to police, but she refused to inform police about the layout of the apartment complex, the offender's whereabouts, and whether the offender was likely to be armed. ${ }^{23}$ Wrongly suspecting that the remaining offender had escaped, officers moved in closer to investigate. As one of the officers inched around a corner of the apartment building, he was fatally shot 15 times in his head, torso, and extremities.

\footnotetext{
${ }^{20}$ Though all data used in the current study stem from publicly available open-source materials, we have taken the extra precaution of not identifying homicide participants and groups.

${ }^{21}$ The offender's run-ins with police included slashing the tires of police cruisers and commanding a dog to attack police officers.

${ }^{22}$ While it was reported that additional individuals were involved in the burglary, they were not involved in the resulting attack on police officers. The female accomplice claimed that it was her belief the group travelled to the residence only to retrieve her belongings, and moreover that she had no reason to expect that other items would be stolen from the home.

${ }^{23}$ Police and prosecutors also suggested that before surrendering to police, the female accomplice provided the offender an assault rifle to use against police.
} 
Other officers could not reach the fallen officer due to suppressing gunfire by the offender, who eventually took his own life with the fallen officer's service weapon. While the transaction stage in this case evolved over an extended period of time, several other homicides categorized as avoiding arrest cases concluded in a much shorter time span. For example, one officer was killed immediately after exiting his patrol cruiser upon discovering a far-right offender burglarizing a feed store.

Mission offense. In our second case, we analyze a mission offense homicide committed by a 67-year-old extreme far-rightist without any known formal ties to organized hate groups. Like most mission offense homicides, the offender operated as a lone actor or "lone wolf." In most cases, mission offenders had spent several years prior to murdering police officers cultivating their scorn for the government. Offenders commonly made threats of violence aimed specifically at police officers. ${ }^{24}$ In this case, the offender had long held vehement antigovernment beliefs and he regularly sparred with authorities over tax issues and zoning ordinances. We also know that the offender displayed violent tendencies at one point shooting over the heads of government officials before being handcuffed and escorted from the town hall by police. ${ }^{25}$ Though the offender would later be described by some as a "ticking time bomb," his attack came as a surprise to the officers who stopped to question him about his rusty tailgate in the summer of $1997 .{ }^{26}$ As the first officer approached his vehicle, the offender shot the officer with a rifle. The wounded officer then crawled to nearby green space before being shot again, this time fatally. When another backup officer arrived on scene, the offender shot and killed him

\footnotetext{
${ }^{24}$ Only one mission offense case failed to reveal observable advanced warning signs.

${ }^{25}$ Of course not all offenders displayed such overt warning signs. Instead, some far-rightists settled for making verbal threats against local authorities or posting threats on social media forums.

${ }^{26}$ While one could argue that the offender was seeking to avoid arrest in this case, his actions prior to and following the homicide indicate that this was not his primary motive.
} 
as well as when he stepped out of his cruiser. It is unlikely that the offender expected that this particular encounter would ignite his deadly rampage. Yet, it is clear that this offender, like most mission offenders, had developed a predetermined means of attack and escape should a violent situation with police or other government authorities arise. Escalation factors were absent in this case and more generally in all mission offenses. Instead, the decisions to commit deadly attacks and plans for executing the attacks had long been established.

After the shootings, the offender drove a fallen officer's police cruiser to the offices of local government officials where he murdered a local judge, whom he had made direct threats against in the past, and a news reporter who attempted to intervene. The offender then fled to his own home where he had rigged an elaborate scheme of tunnels. Authorities would later suggest that the traps were designed to kill police and other first responders. After setting fire to his home, the offender drove across state lines and parked his car on a dead-end embankment. As officers from several state and local agencies responded, the offender laid in wait and fired shots at them from his offensive position. The incident concluded with a fatal gunshot wound to the offender's head. Demonstrated in this case, mission offense actors often commit violent attacks anticipating their own death. Though long, drawn-out standoffs did occur in mission offenses, most mission offenders chose to go out in a blaze of glory by engaging in "suicide by cop." For other mission offenders who surrendered to police, several used the opportunities to espouse their radical anti-government views in court.

Defending property. The offender in our third case study could be described as a disturbed loner and follower of the anti-government Patriot movement. One of his biggest concerns was the ongoing establishment of a New World Order (NWO), a common conspiracy theory of the extreme far-right movement suggesting that government officials are intent on 
disarming citizens and establishing an alternative, Zionist-led government. The extreme farrightist in this case viewed local police as "mafia members" who were ordered by corrupt government actors to implement the NWO's agenda. His prior involvement with local authorities was storied and included countless accusatorial ranting sessions. He had made it abundantly clear that he was in possession of guns and explosives, and that he was fully prepared to use them to protect his home. The offender in this case also had a reputation for acting out against police officers. Indeed, on one previous occasion, the offender was charged with resisting and obstructing police and fleeing an officer of the law.

The offender's preoccupation with the establishment of the NWO likely contributed to the killing of a local police officer in 1998. His paranoia over the violation of his rights led him to engage in the armed patrol of his property. Offenders involved in other defending property cases exhibited similar precursor stage characteristics. Extreme far-rightists routinely alarmed neighbors and potential visitors with protective maneuvers and shows of force. Required to confront extremists about their alarming behaviors, police inadvertently played into their antigovernment conspiracy theories. In some cases, offenders reported that they had long felt that they were the victims of targeted harassment by police.

On the day of the deadly attack in this defending property case, a neighbor called police to report that the offender was pacing back and forth on his front porch while waving a gun. The offender, who believed that the "police mafia" had ordered a hit on his life, was in an agitated mental state when officers arrived. After a two-hour standoff, during which officers attempted to talk the offender into surrendering his weapon, one officer began to approach the front porch with his weapon drawn. Seeing this, the offender retreated into his house and warned the pursuing officer that a firefight would ensue should he step foot into the house. When the officer 
stepped onto the porch, the offender opened fire. As the officer fell to the ground, he fired his weapon and wounded the offender before succumbing to his injuries. In this case, officer actions arguably led to the initiation of violence. Demonstrating government force through the arrival of multiple police vehicles and officers in full tactical gear likely excited the offender's worst fears. He had previously warned officers that he was afraid of their presence and that he did not want them on his property.

Though the offender had suffered a bullet wound to his shoulder, he was able to temporarily barricade himself in his house. Upon the offender surrendering to police, the police credited their crisis negotiator for coaxing him out of his home and potentially saving more lives. The majority of other defending property offenders also participated in standoffs, ranging from 5 hours up to eleven days. Typically, once defending property offenders realized the reality of their situations, they yielded to police force and the rule of law. This differs from avoiding arrest and mission offenders, whose ultimate strategy is to evade police at all costs.

Defending family. The fourth and final case study we include involves a middle-aged sovereign citizen man who made a living providing lectures on ways to the defraud the government. The offender in this case had a prior criminal record consisting mostly of financial crimes and minor violence charges, though he was at one point charged for felonious assault on a thirteen-year-old neighbor. Prior to the attack on police, the offender, along with his teen-aged son, posted threatening videos on social media sites, demonstrating shared their animus toward police. One local sheriff reportedly warned other officers that the offender was unstable and could become violent toward police officers.

The sheriff's warning rang true in 2010 when an exchange between the offender and two troopers conducting a routine traffic stop quickly escalated into a verbal argument followed by a 
physical altercation. With the officers clearly distracted, the offender's sixteen-year-old son exited the passenger side of the vehicle and shot both officers with an assault rifle. The father and son then climbed back into the vehicle and fled the scene, shortly thereafter landing at a nearby shopping center where they took up a defensive position in a parking lot. The pair unloaded round after round of ammunition at responding officers, injuring several of them, before both shooters were killed by police.

The only other defending family case included in our study involved two brothers whose backgrounds were substantially different from the father-and-son-duo described above. Similarly, despite neither family member in this case having a violent criminal history, ${ }^{27}$ this case began with a seemingly routine traffic stop as a triggering event that led to the death and injury of police officers. Additionally, both defended family cases involved offenders' belligerence and ideological rants, which served as warning signs immediately preceding the violent transactions. Offenders' non-compliance with officer demands served to initiate already tense situations that quickly developed into violent exchanges. Moreover, the presence of family members escalated the volatile situations and directly contributed to the fatal outcomes for police. As the belligerent drivers distracted officers, family members in both cases pulled weapons from the passenger seats of stopped vehicles and used them to kill police officers.

\section{Discussion}

Several interesting patterns emerged from our study of far-right police homicides. In particular, we found that violence was very often triggered by routine police work, while surprise attacks and ambushes were common initiators of violent transactions. In cases where escalating

\footnotetext{
${ }^{27}$ Interestingly, the two brothers previously had interests in pursuing careers as police officers.
} 
factors were observed, demonstrations of force by police officers and the introduction of a third party fueled already tense interchanges.

Moving beyond general descriptive statistics, one of the primary goals of this study was to examine how cases compared across different categories of homicide events. Based on our findings, we conclude that far-right police slayings do not all occur in the same manner, and thus, our study also supports previous research suggesting the need to disaggregate cases by meaningful types when studying lethal violence (Flewelling \& Williams, 1999). In other words, our storyline analysis revealed that how homicides are structured can differentially shape dynamic precursor, transaction, and aftermath processes of homicide events. For instance, we found that far-right offenders involved in avoiding arrest homicides were relatively more likely to commit subsequent crimes following police slayings. Also more likely to be fueled by racial hatred, mission offenders posed unique threats to communities before and after deadly attacks targeting police. Our findings clearly show that very little could be done to de-escalate or mitigate mission offenses. Indeed, the initiation of violence for these crimes was sudden and unexpected, and absent of any sort of escalating factors. As discussed more below, it is necessary to separate mission offense attacks out from other categories of far-right police homicides, as different considerations for preventing this type of attack are required. Our findings also showed that while initiating events and escalating factors for defending property and defending family homicide events compared similarly, these two homicide storylines eventually unfolded in very different manners. Property defenders gave clear warnings to police before initiating violence and engaging police in a firefight. On the other hand, defending family offenders failed to give critical warnings to police before murdering them. 
Our findings have several important implications for police, some of which are specific to homicide storyline categories. As recognized by others (ADL, 2001), many deadly far-right attacks on police are often triggered by seemingly routine traffic stops that quickly escalate into deadly violence. Because it is state, local, and tribal (SLT) police officers that will be first to encounter extremists, officers should be trained to identify them. There are a number of signs of which to be aware. For example, while the vast major of drivers with political bumper stickers are not violent, many sovereign citizens and other anti-government far-rightists have "Don't tread on me," "no trespassing," "tax exempt," and other sayings prominently displayed on their vehicles (ADL, 2001; Jackson, 2013; Stanek, 2014). These markers are of course protected by the $1^{\text {st }}$ Amendment right to free speech, but in combination with other suspicious behaviors, they can serve as an indication that extra precaution should be taken. Anti-government extremists may also refuse to post license plates on their vehicles or provide personal identification upon police request. Some extreme far-rightists become argumentative, questioning the authority and jurisdiction of the officers. Usually, they simply want to make a political point and frustrate officers. However, our findings showed that argumentativeness and belligerence can, in some instances, quickly evolve into serious violence. It is crucial for police to understand that for some extremist homicide storylines, especially defending family cases, it was not only the argumentative offender that posed an immediate threat to police. Instead, family members thought to be sitting quietly in the passenger seat can also become a threat to police. In our defending family case study, we saw that while the primary offender exited the vehicle and distracted officers, his son emerged from the vehicle and fired at police. Based on our findings, we suggest that when police officers suspect that persons of interest adhere to sovereign citizens or other anti-government beliefs, they should expect that family members, 1) share the same 
belief system, 2) are armed, and 3) may be willing to use deadly violence against police to defend their kin. In addition to being familiarized with the threats posed by far-rightists, police officers should be trained to defuse potentially tense situations by being agreeable, peaceful, and comprising during verbal exchanges with them. At no point should officers attempt to counter the beliefs and assertions of far-rightists during traffic stop encounters. If a search of the vehicle or arrest is required, officers would be best served to retreat to the relative safety of patrol vehicles and wait for backup to arrive (Stanek, 2014).

Police officers should also expect that family members may be present in the homes of far-right extremists, and that they too might be willing to use violence against them in defense of their homes. Far-right extremists have in the past fortified, booby-trapped, and installed surveillance equipment on their property in preparation for a government takeover. Far-rightists will have access to firearms in their homes. As we saw in the defended property case study, this can have deadly results for police officers. A common tactical approach used by police during residential standoffs is to demonstrate authority and domineering presence as a way to control potentially volatile situations and signal to offenders that resistance is futile. Based on our findings, however, we suggest that strong demonstrations of military-like force may serve only to escalate the violence. In particular, military-style vehicles, weaponry, and other gear play into far-rightists' NWO conspiracy theories and beliefs that the government is preparing for an impending battle war with American citizens. Instead, we suggest that police officers should consider utilizing "softer" techniques when attempting to remove agitated far-right extremists from their homes (see also Freilich \& Chermak, 2009). As the least, softer techniques would entail "backing off" and approaching situations by listening patiently to offenders as they express 
their grievances. In this way, understanding the beliefs of far-right extremists and modifying their tactics to alleviate their fears could potentially enhance the safety of police.

At first glance, our findings seem to suggest that there is little that police officers can do to mitigate the threat posed by far-right mission offenders. The lack of observable initiation and escalation factors present in these situations appear to render them devoid of opportunities for preempting violence. Upon closer examination, however, our study shows that mission offenders were participants in some of the longest and most public radicalization processes, entailing explicitly (and implicitly) made threats against police officers and other government actors. News reports about the homicides often suggested that family, acquaintances, co-workers, community members, and local officials were well aware of offenders' beliefs and their histories of violent behavior. In fact, the "ticking time bomb" was a metaphor used to describe far-right mission offenders on more than one occasion. For mission offenses, offenders posted warnings through written correspondence, blogs, and other digital social media outlets. Unfortunately, it is usually only after a deadly attack on police that the extent and seriousness of threats become apparent. This is due at least in part because of failures to share key information about potential threats. We suggest that advancing intelligence capacities of police agencies can serve to prevent extremist violence and reduce risks to officers (Chermak, Carter, Carter, McGarrell, \& Drew, 2013). A number of existing community-oriented and intelligence-led policing practices may be effective in achieving this aim, including encouraging sharing information across law enforcement agency ranks and through the continued development of inter-agency partnerships, taskforces, and educational seminars. In particular, intelligence-led policing processes could facilitate increased documentation of prior threats to police and processes for relaying information about specific offenders to officers within and across agencies. This would allow 
officers to more accurately assess the risks faced during encounters with extreme far-right individuals. Also important, police agencies must develop and maintain working relationships with key members of the community, such as mental health providers, weapon distributers, and schools to facilitate two-way communication channels for the sharing of pertinent information. Nurturing mutually beneficial and trusting relationships will benefit police, as members of the public will feel increasingly comfortable reporting suspicious behaviors before domestic extremists turn to violence.

\section{Conclusion}

The purpose of our exploratory study was to use data from the United States Extremist Crime Database to advance a more nuanced understanding of the dynamic nature of extreme farright violence by comparatively examining homicides targeting police officers. Though the number of homicide cases in our study was limited, we believe that our mixed-methods approach to data collection and analysis resulted in key insights into the nature of this serious social phenomenon. In particular, our findings confirmed that not all extremist homicides against police occur in the same way, and that differences among these events have important implications for officer training and practice. It is our hope that a better understanding of how homicide processes transition from precursor, transaction, and aftermath stages, under different sets of circumstances (or storylines), will benefit the safety of officers by helping them identify initiation, escalation, and other dynamic factors that contribute to deadly outcomes. 


\section{References}

Agnew, R. (2006). Storylines as a neglected cause of crime. Journal of Research in Crime and Delinquency, 43(2), 119-147.

Anti-Defamation League. (2001). Officer safety and extremists: An overview for law enforcement officers. Anti-Defamation League. Available at http://www.adl.org/learn/safety/default.asp

Anti-Defamation League. (2012). The lawless ones: The resurgence of the sovereign citizen movement. Anti-Defamation League's special report ( $2^{\text {nd }}$ ed.). Available at http://www.adl.org/assets/pdf/combating-hate/Lawless-Ones-2012-Edition-WEBfinal.pdf

Aho, J.A. (1990). The politics of righteousness: Idaho Christian Patriotism. Seattle, WA: University of Washington Press.

Aho, J.A. (1994). This thing of darkness: A sociology of the enemy. University of Washington Press.

Arena, M.P., \& Arrigo, B.A. (2000). White supremacist behavior: Toward an integrated social psychological model. Deviant Behavior, 21(3), 213-244.

Athens, L.H. (1980). Violent criminal acts and actors: A symbolic interactionist study. Boston, MA: Routledge and Kegan Hall.

Barkun, M. (1997). Religion and the racist right: The origins of the Christian Identity movement. Chapel Hill: University of North Carolina Press.

Barkun, M. (1996). Religion, militias, and Oklahoma City: The mind of a conspiratorialist. Terrorism \& Political Violence, 8(1), 50-64.

Batton, C., \& Wilson, S. (2006). Police murders: An examination of historical trends in the killing of law enforcement officers in the United States, 1947-1998. Homicide Studies, 10(2), 79-97.

Baysinger, T.G. (2006). Right-wing group characteristics and ideology. Homeland Security Affairs, 2(2), 1-19.

Bennett, A. \& Elman, C. (2006). Qualitative research: Recent developments in case study methods. Annual Review of Political Science, 9, 455-476.

Berlet, C., \& Vysotsky, S. (2006). Overview of U. S. white supremacist groups. Journal of Political and Military Sociology, 34(1), 11-48. 
Blanchard, D. (1996). The anti-abortion movement: References and resources. New York: Prentice Hall.

Blumer, H. (1969). Symbolic interactionism: Perspective and method. Englewood Cliffs, N.J.: Prentice Hall.

Brannan, D.W. (1999). The evolution of the Church of Israel: Dangerous mutations. Terrorism \& Political Violence, 11(3), 106- 118.

Brown, J. M., \& Langan, P. A. (2001). Policing and homicide 1976-1998: Justifiable homicide by police, police officers murdered by felons. Washington D. C.: U. S. Department of Justice.

Bushart, H.L., Craig, J.R., \& Barnes, M. (1998). Soldiers of God: White supremacists and their holy war for America. New York: Pinnacle Books.

Carderelli, A. P. (1968). An analysis of police killed by criminal action: 1961-1963. The Journal of Criminal Law, Criminology, and Police Science, 59(3), 447-453.

Carlson, J.R. (1995). The future terrorists in America. American Journal of Police, 14, 71-91.

Carter, D., Chermak, S., Carter, J., \& Drew, J. (2014). Understanding law enforcement intelligence processes. College Park, MD: START. Available at https://www.start.umd.edu/pubs/START UnderstandingLawEnforcementIntellige nceProcesses July2014.pdf

Chamlin, M. B. (1989). Conflict theory and police killings. Deviant Behavior, 10(4), 353-368.

Chapman, S. G. (1998). Murdered on duty: The killing of police officers in America ( $2^{\text {nd }}$ ed). Springfield, IL: Charles C. Thomas.

Chapman, S. G. (1986). Cops, killers and staying alive: The murder of police officers in America. Springfield: Charles C. Thomas.

Chermak, S., Carter, J., Carter, D., McGarrell, E. F., Drew, J. (2013). Law enforcement's information sharing infrastructure: A national assessment. Police Quarterly, 16(2), 211244.

Chermak, S.M., Freilich, J. D., Parkin, W., \& Lynch, J. P. (2012). American terrorism and extremist crime data sources and selectivity bias: An investigation focusing on homicide events committed by far-right extremists. Journal of Quantitative Criminology, 28(1), 191-218.

Chermak, S. M., Freilich, J. D., \& Suttmoeller, M. J. (2013). The organizational dynamics of farright hate groups in the United States: Comparing violent and non-violent organizations. Studies in Conflict \& Terrorism, 36(3), 193-218. 
Chermak, S.M., \& Gruenewald, J. (2015). Laying the foundation for the criminological examination of right-wing, left-wing, and Al Qaeda-inspired extremism in the United States. Terrorism \& Political Violence, 27(1), 133-159.

Collins, R. (2008). Violence: A micro-sociological theory. Princeton, N. J.: Princeton University Press.

Cresswell, J.W., \& Plano Clark, V.L.. (2007). Designing and conducting mixed methods research. Thousand Oaks, CA: Sage Publications.

Cresswell, J. W., Plano Clark, V. L., Gutmann, M. L., \& Hanson, W. E. (2003). Advanced mixed methods research designs. In A. Tashakkori \& C. Teddle, (Eds.). Handbook of mixed methods in social \& behavioral research (pp. 209-240). Thousand Oaks, CA: Sage.

Durham, M. (1996). Preparing for Armageddon: Citizen militias, the patriot movement, and the Oklahoma City bombing. Terrorism \& Political Violence, 8(1), 65-79.

Edwards, T. D. (1995). Felonious killings of state police and highway patrol officers: A descriptive and comparative evaluation. American Journal of Police, 14(2), 89-105.

Ezekiel, R.S. (2002). An ethnographer looks at neo-Nazi and Klan groups. American Behavior Scientist, 46(1), 51-71.

FBI Counterterrorism Analysis Section. (2011). Sovereign citizens: A growing domestic threat to law enforcement. FBI Law Enforcement Bulletin. Available from http://www.fbi.gov/stats-services/publications/law-enforcementbulletin/september-2011/sovereign-citizens

Fleisher, M.S., \& Decker, S.H. (2001). An overview of the challenge of prison gangs. Corrections Management Quarterly, 5(1), 1-9.

Flewelling, R.L., \& Williams, K.R. (1999). Categorizing homicides. In M.D. Smith, \& M.A. Zahn (Eds.), Homicide: A sourcebook of social research (pp. 96-106). Thousand Oaks, CA: Sage Publications.

Flint, C. (2001). Right-wing resistance to the process of American hegemony: The changing political geography of nativism in Pennsylvania, 1920-1998. Political Geography, 20, 763-786.

Freilich, J.D., Adamczyk, A., Chermak, S.M., Boyd, K.A., \& Parkin, W.S. (2014). Investigating the applicability of macro-level criminology theory to terrorism: A county-level analysis. Published Online First at Journal of Quantitative Criminology. DOI: 10.1007/s10940014-9239-0. 
Freilich, J.D., \& Chermak, S.M. (2009). Preventing deadly encounters between law enforcement and American far-rightists. Crime Prevention Studies, 25, 141-172.

Freilich, J.D., Chermak, S.M., Belli, R., Gruenewald, J., \& Parkin, W.S. (2014). Introducing the United States Extremist Crime Database. Terrorism \& Political Violence, 26(2), 372-384.

Freilich, J. D., Chermak, S. D., \& Caspi, D. (2009). Critical events in the life trajectories of domestic extremist white supremacist groups: A case study analysis of four violent organizations. Criminology \& Public Policy, 8(3), 497-530.

Gibbs, J.C. (2013). Targeting blue: Why we should study terrorist attacks on police. In D. Lowe, A. Turk, \& Das, D.K. (eds.), Examining political violence: Studies of terrorism, counterterrorism, and internal war (pp. 311-327). Taylor \& Francis/International Police Executive Symposium.

Goffman, E. (1967). Interaction ritual: Essays on face-to-face behavior. New York: Anchor Books.

Grimes, D.A., Forest, J.D., Kirkman, A.L., \& Radford, B. (1991). An epidemic of anti-abortion violence in the United States. Journal of Obstetrics and Gynecology, 165, 1263-1268.

Gruenewald, J. (2011). A comparative examination of far-right extremist homicide events. Homicide Studies, 15, 177-203.

Gruenewald, J., Chermak, S.M., \& Freilich, J.D. (2013a). Distinguishing "loner” attacks from other domestic extremists: A comparison of far-right homicide incident and offender characteristics. Criminology and Public Policy, 12(1), 1-27.

Gruenewald, J., Chermak, S., Freilich, J. D. (2013b). Far-right lone wolf homicides in the United States. Studies in Conflict \& Terrorism, 36, 1005-1024.

Gruenewald, J, Freilich, J.D., \& Chermak, S.M. (2009). A review of the far-right extremism literature. In R. Blazak \& B. Perry (Eds.), Hate crime issues and perspectives. Westport: Praeger.

Gruenewald, J., \& Pridemore, W.A. (2012). A comparison of ideologically-motivated homicides from the new Extremist Crime Database and homicides from the Supplementary Homicides Reports using multiple imputation by chained equations to handle missing values. Journal of Quantitative Criminology, 28, 141-162.

Hamm, M. S. (2007). Terrorism as crime: From Oklahoma city to Al-Qaeda and beyond. New York: New York University Press.

Hamm, M.S. (1993). American skinheads: The criminology and control of hate crime. Westport, CT: Praeger. 
Harris, D. (2010, July 1). Deadly Arkansas shootings by 'Sovereigns' Jerry and Joe Kane who shun U.S. law. ABCNews. Retrieved from http://abcnews.go.com/WN/deadlyarkansas-shooting-sovereign-citizens-jerry-kanejoseph/story?id=11065285\&singlePage=true

Hewitt, C. (2003). Understanding terrorism in America: From the Klan to Al Qaeda. New York: Routledge.

Hewitt, C. (2000). The political context of terrorism in America: Ignoring extremism or pandering to them? Terrorism \& Political Violence, 12, 354-344.

Hoffman, B. (1995). Holy terror: The implications of terrorism motivated by a religious imperative. Studies in Conflict \& Terrorism, 18, 271-284.

Hoffman, B. (1987). Right wing terrorism in the United States. Violence and Aggression and Terrorism, 1, 1-12.

Irwin, J. (1980). Prisons in turmoil. Boston, MA: Little, Brown, and Company.

Jacobs, D., \& Carmichael, J. T. (2002). Subordination and violence against state control agents: Testing political explanations for lethal assaults against the police. Social Forces, 80(4), 1223-1251.

Jackson, T. (2013). Officer safety corner: Sovereign citizens on traffic stops. The Police Chief, 80, 14-15. Available from http://www.policechiefmagazine.org/magazine/index.cfm?fuseaction=display\&arti cle $\mathrm{id}=2862 \&$ issue $\mathrm{id}=22013$

Kaminski, R. J. (2008). Assessing the county-level structural covariates of police homicides. Homicide Studies, 12(4), 350-380.

Kaminski, R. J. (2004). The murder of police officers. New York: LFB Scholarly Publishing LLC.

Kaminski, R. J., \& Marvel, T. B. (2002). A comparison of changes in police and general homicides, 1930-1998. Criminology, 40, 701-720.

Kaminski, R. J., \& Stucky, T. D., (2009). Reassessing political explanations for murders of police. Homicide Studies, 13(1), 3-20.

Kaplan, J. (1996). Absolute rescue: Absolutism, defensive action, and the resort to force. In M. Barkun's (Ed.), Millennialism and violence (pp. 128-163). London: Frank Cass.

Kaplan, J. (1995). Right wing violence in North America. Terrorism \& Political Violence, 7(1), 44-95. 
Kaplan, J. (1993). The context of American millenarianism revolutionary theology: The case of the 'Identity Christian' church of Israel. Terrorism \& Political Violence, 5(1), 30-82.

Kelley, K., \& Gruenewald, J. (2015). Accomplishing masculinity through anti-lesbian, gay, bisexual, and transgender homicide. Men \& Masculinities, 18, 3-29.

Konstantin, D. N. (1984). Homicides of American law enforcement officer, 1978-1980. Justice Quarterly, 1, 29-45.

Lester, D. (1984). The murder of police officers in American cities. Criminal Justice \& Behavior, 11, 101-113.

Lester, D. (1978a). Study of civilian-caused murders of police officers. International Journal of Criminology and Penology, 6(4), 373-378.

Lester, D. (1978b). Predicting murder rates of police officers in urban areas. Police Law Quarterly, 20, 20-25.

Levitas, D. (2002). The terrorist next door: The militia movement and the radical right. New York: St. Martin's Press.

Little, R. E. (1984). Cop killing: A descriptive analysis of the problem. Police Studies: The International Review of Police Development, 7, 68-76.

Luckenbill, D. F. (1977). Criminal homicide as a situated transaction. Social Problems, 25(2), 176-186.

Meier, R.F., Kennedy, L.W., \& Sacco, V. F. (2001). The process and structure of crime: Criminal events and crime analysis. Advances in Criminological Theory, 9, 1-27.

Michael, G. (2003). Confronting right-wing extremism and terrorism in the USA. New York: Routledge.

Neiwert, D. A. (1999). In God's country: The patriot movement and the Pacific Northwest. Pullman, WA: Washington State University Press.

Orlando-Morningstar, D. (1997, October). Prison gangs. Special Needs Offender Bulletin, 2, 113.

Parkin, W.S., \& Freilich, J.D. (2015). Routine activities and right-wing extremists: An empirical comparison of the victims of ideologically-and non-ideologicallymotivated homicides committed by American far-rightists. Terrorism \& Political Violence, 27(1), 182-203

Parkin, W.S., Freilich, J.D., \& Chermak, S.M. (2015). Ideological victimization: Homicides perpetrated by far-right extremists. Homicide Studies, 19(3), 211-236. 
Pelz, M.E., Marquart, J.W., \& Pelz, C.T. (1991). Right-wing extremism in the Texas prisons: The rise and fall of the Aryan Brotherhood of Texas. The Prison Journal, 71, 23-37.

Perliger, A. (2012). Challengers from the sidelines: Understanding America's violent far-right. Combating Terrorism Center. West Point. Retrieved from https://www.ctc.usma.edu/v2/wpcontent/uploads/2013/01/ChallengersFromtheSidelines.pdf

Peterson, R. D., \& Bailey, W. C. (1988). Structural influences on the killing of police: A comparison with general homicides. Justice Quarterly, 5(2), 207-233.

Pinizzotto, A. J., \& Davis, E. F. (1992). Killed in the line of duty: A study of selected felonious killings of law enforcement officers. Washington D. C.: U. S. Department of Justice.

Sacco, V. F., \& Kennedy, L.W. (1996). The criminal event. Belmont, CA: Wadsworth.

Sharpe, T.T. (2000). The identity Christian movement: Ideology of domestic terrorism. Journal of Black Studies, 30(4), 604-623.

Smith, B. L. (1994). Terrorism in America: Pipe bombs and pipe dreams. Albany: State University of New York Press.

Sprinzak, E. (1995). Right-wing terrorism in a comparative perspective: The case of split delegitimization. Terrorism \& Political Violence, 7(1), 17-43.

Stanek, R. (2014). Sovereign citizen movement and its impact. Available from http://www.ourdigitalmags.com/article/Sovereign Citizen Movement and Its Imp act/1613046/192872/article.html

Suttmoeller, M.J., Gruenewald, J., Chermak, S.M., \& Freilich, J.D. (2013). Killed in the line of duty: Comparing police homicides committed by far-right extremists to all police homicides. Law Enforcement Executive Forum, 13(1), 45-64.

Tashakkori, A., \& Teddlie, C. (1998). Mixed methodology: Combining qualitative and quantitative approaches. Thousand Oaks, CA: Sage.

Whitsel, B. (2001). Ideological mutation and millennial belief in the America neo-Nazi movement. Studies in Conflict \& Terrorism, 24, 89-106.

Wilbanks, W. (1994). Cops killed and cop-killers: An historical perspective. American Journal of Police, 13(1), 31-49.

Wilson, M., \& Lynxwiler, J. (1988). Abortion clinic violence as terrorism. Terrorism, 11, 263273. 


\section{TABLES}

Table 1. Precursor Stage Attributes by Homicide Storyline

\begin{tabular}{lccccc}
\hline Variable Name & $\begin{array}{c}\text { Total } \\
\text { Homicides }\end{array}$ & $\begin{array}{c}\text { Avoiding } \\
\text { Arrest }\end{array}$ & $\begin{array}{c}\text { Mission } \\
\text { Offense }\end{array}$ & $\begin{array}{c}\text { Defending } \\
\text { Property }\end{array}$ & $\begin{array}{c}\text { Defending } \\
\text { Family }\end{array}$ \\
\hline Triggering Event & & & & & \\
$\quad$ Traffic Stop & $7(23.3 \%)$ & $2(14.3 \%)$ & $2(25.0 \%)$ & $1(16.7 \%)$ & $2(100.0 \%)$ \\
Response to 911 Call & $6(20.0 \%)$ & $2(14.3 \%)$ & $1(12.5 \%)$ & $3(50.0 \%)$ & - \\
Routine Activity & $6(20.0 \%)$ & - & $5(62.5 \%)$ & $1(16.7 \%)$ & - \\
Commission of Another Crime & $5(16.7 \%)$ & $5(35.7 \%)$ & - & - & - \\
Issuance of Arrest Warrant/Arrest & $4(13.3 \%)$ & $3(21.4 \%)$ & - & $1(16.7 \%)$ & - \\
Police Investigation of Unrelated Crime & $1(3.3 \%)$ & $1(7.1 \%)$ & - & - & - \\
Welfare Check & $1(3.3 \%)$ & $1(7.1 \%)$ & - & - & - \\
Immediate Warning Signs & & & & - & - \\
No Immediate Warning Signs & $16(53.3 \%)$ & $8(57.1 \%)$ & $6(75.0 \%)$ & $2(33.3 \%)$ & - \\
Police Knowledge that Suspect Has a Weapon & $6(20.0 \%)$ & $3(21.4 \%)$ & - & $3(50.0 \%)$ & - \\
Stating Ideological Views & $3(10.0 \%)$ & $1(7.1 \%)$ & $1(12.5 \%)$ & - & $1(50.0 \%)$ \\
Belligerence During Interaction/Arrest & $2(6.7 \%)$ & $1(7.1 \%)$ & - & - & $1(50.0 \%)$ \\
Direct Warning of Intent to Use Violence & $2(6.7 \%)$ & $1(7.1 \%)$ & - & $1(16.7 \%)$ & - \\
Bomb Threat & $1(3.3 \%)$ & - & $1(12.5 \%)$ & - & - \\
\hline
\end{tabular}

a. These are duties unrelated to law enforcement and responding to calls for service. Examples of routine activity include eating lunch and filling up the police cruiser with gas.

b. In two of these cases, police knew that shots had been fired. 
Table 2. Transaction Stage Attributes by Homicide Storyline

\begin{tabular}{|c|c|c|c|c|c|}
\hline Variable Name & $\begin{array}{c}\text { Total } \\
\text { Homicides }\end{array}$ & $\begin{array}{c}\text { Avoiding } \\
\text { Arrest }\end{array}$ & $\begin{array}{l}\text { Mission } \\
\text { Offense }\end{array}$ & $\begin{array}{l}\text { Defending } \\
\text { Property }\end{array}$ & $\begin{array}{c}\text { Defending } \\
\text { Family }\end{array}$ \\
\hline \multicolumn{6}{|l|}{ Initiation of Violence } \\
\hline Offender Attacks by Surprise & $14(46.7 \%)$ & $7(50.0 \%)$ & $6(75.0 \%)$ & - & $1(50.0 \%)$ \\
\hline Offender Ambush (Lying in Wait) & $6(20.0 \%)$ & $3(21.4 \%)$ & - & $3(50.0 \%)$ & - \\
\hline Offender Fires Weapon(s) at Officers & $4(13.3 \%)$ & $2(14.3 \%)$ & - & $2(33.3 \%)$ & - \\
\hline Officer Actions (Use of Lethal Violence) & $2(6.7 \%)$ & - & - & $1(16.7 \%)$ & $1(50.0 \%)$ \\
\hline Offender Plants Bomb & $2(6.7 \%)$ & - & $2(25.0 \%)$ & - & - \\
\hline Physical Struggle & $1(3.3 \%)$ & $1(7.1 \%)$ & - & - & - \\
\hline Officer Actions (Use of Non-Lethal Violence) & $1(3.3 \%)$ & $1(7.1 \%)$ & - & - & - \\
\hline \multicolumn{6}{|l|}{ Escalation Factors } \\
\hline No Escalation Factors & $16(53.3 \%)$ & $6(42.9 \%)$ & $8(100.0 \%)$ & $2(33.3 \%)$ & - \\
\hline Introduction of a Third Party Action & $6(20.0 \%)$ & $3(21.4 \%)$ & - & $1(16.7 \%)$ & $2(100.0 \%)$ \\
\hline Actions of Police - Show of Force & $3(10.0 \%)$ & $1(7.1 \%)$ & - & $2(33.3 \%)$ & - \\
\hline Actions of Police - Hero & $3(10.0 \%)$ & $2(14.3 \%)$ & - & $1(16.7 \%)$ & - \\
\hline Struggle Over Weapon & $1(3.3 \%)$ & $1(7.1 \%)$ & - & - & - \\
\hline Police Equipment Malfunction & $1(3.3 \%)$ & $1(7.1 \%)$ & - & - & - \\
\hline \multicolumn{6}{|l|}{ Weapon Type } \\
\hline Handgun & $11(36.7 \%)$ & $6(42.9 \%)$ & $3(37.5 \%)$ & $1(16.7 \%)$ & $1(50.0 \%)$ \\
\hline Multiple Weapons & $8(26.7 \%)$ & $5(35.7 \%)$ & $1(12.5 \%)$ & $2(33.3 \%)$ & - \\
\hline Assault Rifle & $6(20.0 \%)$ & $2(14.3 \%)$ & $1(12.5 \%)$ & $2(33.3 \%)$ & $1(50.0 \%)$ \\
\hline Long Gun & $3(10.0 \%)$ & $1(7.1 \%)$ & $1(12.5 \%)$ & $1(16.7 \%)$ & - \\
\hline Bomb & $2(6.7 \%)$ & - & $2(25.0 \%)$ & - & - \\
\hline \multicolumn{6}{|l|}{ Number of Far-Right Offenders } \\
\hline One & $19(63.3 \%)$ & $10(71.4 \%)$ & $6(75.0 \%)$ & $3(50.0 \%)$ & - \\
\hline Two & $9(30.0 \%)$ & $3(21.4 \%)$ & $2(25.0 \%)$ & $2(33.3 \%)$ & $2(100.0 \%)$ \\
\hline Three or More & $2(6.7 \%)$ & $1(7.1 \%)$ & - & $1(16.7 \%)$ & - \\
\hline \multicolumn{6}{|l|}{ Number of Officers Killed } \\
\hline One & $19(63.3 \%)$ & $11(78.6 \%)$ & $3(37.5 \%)$ & $4(66.7 \%)$ & $1(50.0 \%)$ \\
\hline Two & $9(30.0 \%)$ & $2(14.3 \%)$ & $4(50.0 \%)$ & $2(33.3 \%)$ & $1(50.0 \%)$ \\
\hline Three or More & $2(6.7 \%)$ & $1(7.1 \%)$ & $1(12.5 \%)$ & - & - \\
\hline Offender Intoxication (Yes) & $7(23.3 \%)$ & $4(28.6 \%)$ & $1(12.5 \%)$ & $1(16.7 \%)$ & $1(50.0 \%)$ \\
\hline Bystanders (Yes) & $14(46.7 \%)$ & $9(64.3 \%)$ & $2(25.0 \%)$ & $1(16.7 \%)$ & $2(100.0 \%)$ \\
\hline
\end{tabular}


Table 3. Aftermath Stage Attributes by Homicide Storyline

\begin{tabular}{|c|c|c|c|c|c|}
\hline Variable Name & $\begin{array}{c}\text { Total } \\
\text { Homicides } \\
\end{array}$ & $\begin{array}{c}\text { Avoiding } \\
\text { Arrest }\end{array}$ & $\begin{array}{l}\text { Mission } \\
\text { Offense }\end{array}$ & $\begin{array}{c}\text { Defending } \\
\text { Property }\end{array}$ & $\begin{array}{c}\text { Defending } \\
\text { Family }\end{array}$ \\
\hline Offender Fled (Yes) & $21(70.0 \%)$ & $11(78.6 \%)$ & $7(87.5 \%)$ & $2(33.3 \%)$ & $1(50.0 \%)$ \\
\hline \multicolumn{6}{|l|}{ Flight Path/Destination } \\
\hline Travel to a Residence ${ }^{a}$ & $5(23.8 \%)$ & $3(27.3 \%)$ & $1(14.3 \%)$ & $1(50.0 \%)$ & - \\
\hline Vehicle Chase & $4(19.1 \%)$ & $3(27.3 \%)$ & $1(14.3 \%)$ & - & - \\
\hline Travel Out of State & $4(19.1 \%)$ & $2(18.2 \%)$ & $2(28.6 \%)$ & - & - \\
\hline Escape to Wooded Area & $3(14.3 \%)$ & $2(18.2 \%)$ & - & $1(50.0 \%)$ & - \\
\hline Travel to Other (e.g., hotel, church) & $3(14.3 \%)$ & $1(9.1 \%)$ & $2(28.6 \%)$ & - & - \\
\hline Travel to Large Retail Store & $2(9.5 \%)$ & - & $1(14.3 \%)$ & - & $1(100.0 \%)$ \\
\hline Offender Commits Subsequent Crime (Yes) & $13(43.3 \%)$ & $8(57.1 \%)$ & $4(50.0 \%)$ & - & $1(50.0 \%)$ \\
\hline Standoff Occurs (Yes) & $18(60.0 \%)^{\mathrm{b}}$ & $10(71.4 \%)^{\mathbf{b}}$ & $3(37.5 \%)$ & $4(66.7 \%)$ & $1(50.0 \%)$ \\
\hline \multicolumn{6}{|l|}{ Conclusion of the Standoff } \\
\hline Surrender & $9(50.0 \%)$ & $5(50.0 \%)$ & - & $4(100.0 \%)$ & - \\
\hline Death in Shootout & $6(33.3 \%)^{\mathbf{c}}$ & $2(20.0 \%)^{\mathrm{c}}$ & $3(100.0 \%)$ & - & $1(100.0 \%)$ \\
\hline Suicide & $2(11.1 \%)$ & $2(20.0 \%)$ & - & - & - \\
\hline Escape & $1(5.6 \%)$ & $1(10.0 \%)$ & - & - & - \\
\hline \multicolumn{6}{|l|}{ Death of One or More Offenders } \\
\hline Yes, Shot by Officers & $11(36.7 \%)$ & $4(28.6 \%)$ & $4(50.0 \%)$ & $1(16.7 \%)$ & $2(100.0 \%)$ \\
\hline Yes, Suicide & $4(13.3 \%)$ & $3(21.4 \%)$ & $1(12.5 \%)$ & - & - \\
\hline No & $15(50.0 \%)$ & $7(50.0 \%)$ & $3(37.5 \%)$ & $5(83.3 \%)$ & - \\
\hline Arrest of One or More Offenders (Yes) & $16(53.3 \%)$ & $8(57.1 \%)$ & $3(37.5 \%$ & $5(83.3 \%)$ & - \\
\hline
\end{tabular}

a. Offender's home, neighbor's home, random home, etc.

b. One standoff occurred during the transaction stage prior to the initial homicide.

c. In one case an offender died in a shootout while a second offender escaped to the neighboring state where she was arrested. 